\title{
STRATEGI KOMUNIKASI PEMASARAN PT. CIPUTRA RESIDENCE DALAM MENINGKATKAN MINAT BELI KONSUMEN
}

\author{
Faisal Tomi saputra, S.Ikom,.M.Si.
}

\author{
Devi Oktaviani
}

Ftsaputra@unis.ac.id

Prodi Ilmu Komunikasi, Fakultas Ilmu Sosial \& Ilmu Politik. Universitas Islam Syekh Yusuf

Tangerang

\begin{abstract}
ABSTRAK
"Strategi Komunikasi Pemasaran PT. Ciputra Residence Dalam Meningkatkan Minat Beli Konsumen". Menghadirkan sebuah kawasan yang dilengkapi berbagai fasilitas menjadi salah satu keunggulan dari PT. Ciputra Residence untuk menarik minat beli konsumen. Penelitian ini menggunakan metode penelitian kualitatif, dengan tradisi penelitian studi kasus. Teknik pengumpulan data yang digunakan adalah observasi dan melakukan wawancara secara mendalam terhadap subjek penelitian. Berdasarkan hasil penelitian strategi komunikasi pemasaran yang dilakukan PT. Ciputra Residence dalam meningkatkan minat beli konsumen adalah melalui bauran pemasaran. Bauran pemasaran di PT. Ciputra residence meliputi, pengenalan produk hunian kepada konsumen, harga hunian yang disesuaikan dengan tipe, kemudian promosi yang dilakukan dengan memanfaatkan media sosial, media cetak ,dan kerja sama dengan radio. Selain itu pendistribusian juga dilakukan di kantor pemasaran maupun di mall, sumber daya manusia yang berkualitas menjadi salah satu hal penting di PT. Ciputra Residence, dan proses dilakukan dengan standar operasional perusahan, kemudian bukti fisik PT. Ciputra Residence yaitu, sebuah kawasan yang secara geografis jauh dari banjir dan tata kota mandiri yang memperlihatkan kemewahan, keunikan, dan elegansi sebuah hunian.
\end{abstract}

Kata kunci : Strategi Komunikasi Pemasaran, Minat Beli, Teori 7P

\begin{abstract}
ABSTRAK
"Marketing Communication Strategy PT. Ciputra Residence In Increasing Consumer Purchase Interest". And having many facilities is one of exellence place, makes consumer interested to their product. This study was descriptive qualitative with case study, and observation with depth interview as instrument data collection. The result of this study was the marketing mix communication strategy of PT. Ciputra Residence increased customer interested and customer purchase with marketing mix activities. Marketing mix of PT. Ciputra Residence is introducing their product, with adjustable price and the promotion announced at social media, printed media, and cooperate with radio. the distribution of the product is conducted in their marketing office and mall. The human resource is important for PT. Ciputra Residence and it
\end{abstract}


processed by operational standard. The residence physical evident built at free floods area and shows a luxury, uniqueness, and elegance of a residence.

Keywords: Marketing Communication Strategy, Purchase Interest, 7P Theory

\section{PENDAHULUAN}

Minat konsumen merupakan suatu hal yang penting untuk dikembangkan oleh perusahaan. Karena peminatan dari konsumen dapat meningkatkan profit suatu perusahaan di setiap tahunnya. Pada

dasarnya konsumen memiliki kecenderungan untuk membeli suatu produk yang menjadi sebuah kebutuhan maupun hanya sebuah keinginan, dari banyaknya konsumen tentu mereka akan berfikir apakah produk yang nanti akan dibeli merupakan suatu kebutuhan yang dapat digunakan dalam jangka waktu yang lama. Seperti salah satunya adalah kebutuhan berupa hunian.

Didalam sebuah perusahaan dibutuhkannya strategi, dimana strategi berguna untuk dapat menarik minat beli konsumen terhadap produk yang ada. Namun pada kenyataannya menarik minat konsumen sangatlah tidak mudah, karena diperlukannya kepercayaan dan semangat yang tinggi untuk bisa menawarkan sebuah produk kepada konsumen.

Sehingga untuk bisa menawarkan konsumen dibutuhkan kemampuan untuk berkomunikasi antara sales dengan konsumen, agar konsumen menjadi tertarik dan berminat untuk membeli produk. Terutama perusahaan yang bergerak dibidang properti perumahan yang tentunya memiliki strategi untuk direncanakan dengan sangat matang.

PT. Ciputra Residence merupakan anak perusahaan dari Group Ciputra, yang juga salah satu pengembang properti terbesar di Indonesia dengan fokus pengembangan skala kota serta mixed-uses development. Terdapat berbagai fasilitas yang dapat digunakan dan dimanfaatkan oleh konsumen yang berada dikawasan Citra Raya. Fasilitas yang disediakan berupa: fasilitas wahana anak, hiburan, rumah sakit,

mall, tempat perbelanjaan, tempat beribadah, sekolah, dan kesehatan, jogging trake, dan taman.

Kegiatan pemasaran merupakan kegiatan yang dilakukan setiap perusahaan untuk bisa membujuk, mempromosikan, dan menarik konsumen untuk bisa membeli produk yang ditawarkan perusahaan. Kegiatan promosi yang dilakukan dengan memanfaatkan media sosial, di era digital sekarang ini sudah banyak perusahaan properti yang memanfaatkan media sebagai alat promosi yang dilakukan, selain media sosial yang diharus digunakan media cetak pun menjadi media yang sering digunakan perusahaan properti untuk memberikan informasi mengenai produk yang ingin dilaunching oleh perusahaan. Media cetak yang dapat digunakan seperti: spanduk, brosur, dan baliho, dalam kegiatan promosi menggunakan media cetak akan 
mempermudah perusahaan untuk menampilkan produk yang harus diketahui konsumen.

Dalam melakukan kegiatan pemasaran di PT. Ciputra Residence dilakukan oleh bagian marketing khusus yang langsung menangani konsumen atau klien yang ingin membeli rumah di kawasan Citra Raya, marketing merupakan salah satu bagian yang penting pada perusahaan properti, karena marketing memiliki tugas untuk membujuk, dan memberikan informasi serta membuat konsumen atau klien percaya dengan keunggulan atau benefit sehingga akan menimbulkan keinginan konsumen agar minat untuk membeli hunian di Citra Raya.

Komunikasi sangatlah erat hubungannya dengan proses kegiatan pemasaran suatu perusahaan. Agar proses kegiatan dapat efektif, maka diperlukan kerjasama yang dilakukan oleh setiap karyawan yang berperan dalam kegiatan pemasaran, dengan demikian dapat membantu perusahaan untuk memasarkan produk sehingga dapat meningkatkan minat beli konsumen. Walaupun PT. Ciputra Residence sudah memiliki nama yang cukup terkenal namun harus tetap disadari bahwa peminatan terhadap produk berupa hunian semakin meningkat setiap tahunnya karena kebutuhan masyarakat yang juga ikut meningkat, oleh sebab itu diperlukan strategi perusahaan untuk meningkatkan minat beli konsumen, dengan memberikan berbagai keunggulan yang akan didapat konsumen selain itu menganalisis perkembangan zaman yang semakin modern sehingga produk yang ditawarkan memiliki suatu kelebihan dimata konsumen. Dimana kebutuhan konsumen menjadi sebuah prioritas utama PT. Ciputra Residence.

Strategi merupakan sebuah rencana yang dirancang oleh perusahaan untuk mendapatkan hasil yang diinginkannya, dan dapat berdampak baik untuk kemajuan perusahaan dimasa yang akan datang. Strategi harus dirancang dengan matang agar rencana yang sudah dibuat dapat sesuai dengan sasaran yang ingin dituju.

Dengan demikian komunikasi pemasaran berperan untuk membantu meningkatkan penjualan rumah atau hunian dari kawasan Citra Raya, komunikasi pemasaran dilakukan oleh bagian marketing dan karyawan lainnya yang juga ikut membantu proses komunikasi pemasaran dalam penjualan produk, berdasarkan latar belakang di atas peneliti tertarik ingin meneliti masalah ini dalam bentuk skripsi yang bertema "Strategi Komunikasi

\section{Pemasaran PT. Ciputra Residence Dalam Meningkatkan Minat Beli Konsumen"}

\section{Rumusan Masalah}

Berdasarkan uraian yang telah dikemukakan diatas maka, dapat dirumuskan masalah sebagai berikut:

\section{"Bagaimana Strategi Komunikasi Pemasaran PT. Ciputra Residence dalam Meningkatkan Minat Beli Konsumen?"'}

\section{Identifikasi Masalah}

Berdasarkan uraian rumusan masalah diatas, dapat diidentifikasikan beberapa masalah sebagai berikut: 
1).Bagaimana strategi bauran pemasaran yang dilakukan PT.

Ciputra Residence dalam meningkatkan minat beli konsumen?

2).Apa saja kendala- kendala PT. Ciputra Residence dalam menarik minat beli konsumen?

\section{TINJAUAN PUSTAKA}

\section{Teori Bauran Pemasaran}

"Bauran pemasaran (marketing mix) adalah seperangkat alat pemasaran yang digunakan perusahaan untuk terus-menerus mencapai tujuan sarannya di pasar sasaran (Kotler, 2004:18)". Menurut Alma (2005:205) "menyatakan bahwa marketing mix atau bauran komunikasi pemasaran adalah

Strategi mengkombinasikan kegiatan - kegiatan pemasaran, agar tercipta kombinasi sehingga muncul hasil paling memuaskan". Sementara menurut Salaudin (2003:3) "mengartikan bahwa bauran pemasaran marketing mix adalah serangkaian dari variabel pemasaran yang dapat dikuasai oleh perusahaan dan digunakan untuk mencapai tujuan dalam pasar sasaran".

\section{LANDASAN KONSEPTUAL Strategi}

Salah satu tujuan sebuah perusahaan adalah mendapatkan keuntungan, keberhasilan dan menjadi perusahaan yang baik dimata masyarakat. Menurut Hafied (2014:64) "kata strategi berasal dari bahasa yunani klasik yaitu "stratos" yang artinya tentara dan kata "agein" yang berarti memimpin. Dengan demikian dapat digabungkan menjadi mempimpin tentara. Kemudian muncul kata "strategos" yang berarti pemimpin tentara pada tingkat atas. Jadi strategi merupakan konsep militer yang bisa diartikan sebagai seni perang para jendral (the art of general), atau suatu rancangan

yang terbaik untuk memenangkan peperangan. Strategi adalah seni dimana melibatkan kemampuan intelegensi/ pikiran untuk membawa semua sumber daya yang tersedia dalam mencapai tujuan dengan memperoleh keuntungan yang maksimal dan efisien".

Menurut Ruslan (2003:31) "strategi adalah suatu perencanaan dari manajemen untuk mencapai tujuan tertentu dalam mencapai tujuan operasionalnya". Selain itu adapun pengertian lainnya mengenai strategi yaitu "strategi adalah rencana berskala besar, dengan orientasi masa depan, guna berinteraksi dengan kondisi persaingan untuk mencapai tujuan perusahaan" (Pearce II dan Robinson, 2008:2).

\section{Komunikasi}

Menurut Ruben dan Stewart (dalam Suryanto, 2015:51) "komunikasi merupakan proses yang menjadi dasar pertama memahami hakikat manusia. Dikatakan sebagai proses karena ada aktivitas yang melibatkan peranan banyak elemen atau tahapan yang meskipun terpisah-pisah, tahapan ini saling sepanjang waktu. Contoh: dalam suatu percakapan yang sederhana selalu ada langkah, seperti penciptaan pesan, pengiriman, penerimaan dan intepretasi 
terhadap pesan". Selain itu menurut Mulyana (dalam Suryanto, 2015:48) "komunikasi adalah interaksi antara dua mahluk hidup atau lebih sehingga para peserta komunikasi mungkin termasuk hewan, tanaman bahkan jin. Dalam definisi tersimpul tujuan yaitu, memberi tahu atau mengubah sikap (attitude), pendapat (oponion) atau perilaku (behavior). Ditinjau

dari segi penyampaian pernyataan. Komunikasi bersifat komunikatif dan persuasif, komunikasi persuasif lebih sulit dari pada komunikasi informatif. Hal ini karena mudah untuk mengubah sikap, pendapat, atau perilaku seseorang atau sejumlah orang".

\section{Komunikasi Pemasaran}

Komunikasi pemasaran menurut Kotler dan Keller (2008:172) "sarana dimana perusahaan berusaha

menginformasikan, membujuk dan mengingatkan konsumen secara langsung maupun tidak langsung tentang produk merek yang dijual". Menurut Alma (2005:205) "menyatakan bahwa marketing mix atau bauran komunikasi pemasaran adalah strategi mengkombinasikan kegiatan-kegiatan pemasaran, agar tercipta kombinasi sehingga muncul hasil paling memuaskan". Sementara menurut Saladin (2003:3) "mengartikan bahwa bauran pemasaran marketing mix adalah serangkaian dari variabel pemasaran yang dapat dikuasai oleh perusahaan dan digunakan untuk mencapai tujuan dalam pasar sasaran". Selain itu menurut Kennedy dan Soemanagara (2006:5) "komunikasi pemasaran adalah kegiatan pemasaran dengan menggunakan teknik-teknik komunikasi yang bertujuan untuk memberikan informasi pada banyak orang agar tujuan perusahaan tercapai, yaitu terjadinya peningkatan pendapatan atas penggunaan jasa atau pembelian produk yang ditawarkan selain itu, komunikasi pemasaran merupakan bentuk komunikasi yang bertujuan untuk memperkuat strategi pemasaran guna, meraih segmentasi yang luas".

\section{Unsur-unsur Bauran Pemasaran}

Kotler (dalam Hermawan, 2012:33) "mengemukakan bahwa bauran pemasaran sebagai serangkaian variabel pemasaran terkendali yang dipakai oleh perusahaan untuk menghasilkan tanggapan yang dikendalikan perusahaan untuk mempengaruhi permintaan produknya, dikenal dengan "4P" yaitu, product, price, promotion, place. Teori bauran pemasaran juga terus berkembang dalam perkembangannya, dikenal juga dengan istilah 7P dimana 3P yang selanjutnya adalah people, physical evidence, process". Terdapat unsur- unsur bauran komunikasi pemasaran sebagai berikut.

\section{1). Product (produk)}

"Produk adalah seperangkat atribut baik berwujud maupun tidak berwujud, termasuk didalamnya masalah warna, harga, nama baik pabrik, nama baik toko yang menjual (pengecer) dan pelayanan pabrik serta pelayanan pengecer, yang diterima oleh pembeli guna memuaskan keinginannya" (Stanton,1981:192). "Produk adalah segala sesuatu yang diharapkan dapat memenuhi kebutuhan manusia ataupun organisasi. Suatu perusahaan sering kali menjual atau 
memasarkan tidak satu produk saja tetapi bermacam produk yang dipasarkannya. Karena dengan memasarkan banyak macam produk maka perusahaan akan memperoleh stabilitas hasil yang lebih tinggi. Sedangkan perusahaan yang hanya menjual satu macam produk jika produk tersebut mengalami kegagalan atau tidak disenangi lagi konsumen, maka perusahaan akan mengalami kesulitan" (Gitosudarmo dalam Danang, 2012:69).

\section{2). Price (Harga)}

Menurut Alma (2005:169) "harga, nilai, dan utility, merupakan konsep yang saling berhubungan, yang dimaksud dengan utility adalah suatu atribut yang melekat pada suatu barang, yang memungkinkan barang tersebut, dapat memenuhi kebutuhan (needs), keinginan (wants) dan memuaskan konsumen satisfaction). Value adalah suatu produk untuk ditukarkan dengan produk nilai lain. Nilai ini dapat dilihat dari situasi barter yaitu pertukaran antara barang dengan barang. Sekarang ini ekonomi kita tidak melakukan barter lagi, akan tetapi sudah menggunakan uang sebagai ukuran yang disebut harga. Jadi harga (price) adalah nilai suatu barang yang dinyatakan dengan uang".

\section{3). Promotion (Promosi)}

Menurut Hamdani (dalam danang, 2012:154) "promosi merupakan satu variabel dalam bauran pemasaran dalam memasarkan produk. Kegiatan promosi bukan saja berfungsi sebagai alat komunikasi antara perusahaan untuk mempengaruhi konsumen, melainkan juga sebagai alat untuk mempengaruhi konsumen dalam kegiatan pembelian atau penggunaan produk sesuai dengan kebutuhan dan keinginannya". Selain itu menurut Kotler (dalam Susyanto, 2014:34) "promosi adalah kegiatan yang dilakukan oleh perusahaan untuk

mengkomunikasikan manfaat dari produknya dan untuk meyakinkan konsumen sasaran untuk membeli produknya. Adapun variabel yang terkandung dalam bauran promosi adalah periklanan, personal selling, promosi langsung, dan publisitas".

3). Place (Tempat pendistribusian)

Menurut Etzel (dalam danang, 2012:172) "saluran distribusi terdiri dari serangkaian lembaga yang melakukan semua kegiatan yang digunakan untuk

menyalurkan produk dan status kepemilikannya dari produsen ke konsumen akhir atau pemakai bisnis". Menurut Danang Sunyoto (2014:171) menjelaskan bahwa "bauran pemasaran yang keempat adalah place atau lebih dikenal dengan saluran distribusi produk dari gudang penyimpanan untuk disalurkan ke agen besar, agen kecil, pengecer, dan terakhir toko, took swalayan dan warung- warung tradisional, yang pada akhirnya bertemu transaksi dengan para konsumen".

5). People (Sumber Daya Manusia) 
"Perencanaan sumber daya manusia (SDM) merupakan fungsi yang pertamatama harus dilaksanakan dalam organisasi. Perencanaan SDM adalah langkah tertentu yang diambil oleh manajemen guna menjamin bahwa bagi organisasi tersedia tenaga kerja yang tepat untuk menduduki berbagai kedudukan, jabatan, dan pekerjaan yang tepat pada waktu yang tepat. Kesemuanya itu dalam rangka mencapai tujuan dan berbagai sasaran yang telah dan akan ditetapkan" (Faustinus, 2003:53). Selanjutnya menurut Faustinus (2003:91) "yaitu kebutuhan sumber daya manusia dipikirkan dan direncanakan, maka langkah selanjutnya adalah melaksanakan analisis dan klasifikasi pekerjaan. Analisis pekerjaan adalah mengumpulkan informasi mengenai suatu pekerjaan yang dilakukan oleh karyawan, yang dilaksanakan dengan cara mengamati atau mengadakan wawancara, dengan bukti-bukti yang benar dari supervisor".

\section{6). Process (Proses)}

"Strategi proses berhubungan dengan tata letak ruang alur produksi dan alur penjualan produk. Tata letak merupakan suatu keputusan penting yang menentukan efisiensi sebuah operasi jangka panjang. Tata letak memiliki banyak dampak strategis karena tata letak menentukan daya saing perusahaan dalam hal kapasitas, proses, fleksibilitas, dan biaya, serta kualitas lingkungan kerja, kontak pelanggan dan citra perusahaan. Tata letak yang efektif dapat membantu organisasi mencapai sebuah strategi yang menunjang diferensiasi, biaya rendah, atau respon cepat" (Jay Hazer, 2006:450).

\section{7) Physical Evidence (Bukti Fisik)}

"Physical evidence merupakan lingkungan dimana suatu perusahaan memberikan layanannya dan lokasi dimana perusahaan dapat berinteraksi dengan konsumen, serta berbagai komponen yang tampak (tangible) dalam menunjang kinerja dan kelancaran pelayanan" (Zeithaml, Bitner, dan Gremler. 2006).

\section{Minat Beli}

Menurut Swastha dan Irawan (dalam Ruri \& Hendra, 2001:339) "minat beli berhubungan dengan perasaan dan emosi, bila seseorang merasa senang dan puas dalam membeli barang atau jasa maka hal itu akan memperkuat minat beli, ketidakpuasan biasanya menghilangkan minat. Minat beli yang ada dalam diri konsumen merupakan fenomena yang sangat penting dalam kegiatan pemasaran, minat beli merupakan suatu perilaku konsumen yang melandaskan suatu keputusan pembelian yang hendak dilakukan”.

\section{Perilaku Konsumen}

Menurut Engel (dalam Etta dan Sopiah, 2013:7) berpendapat bahwa "perilaku konsumen adalah tindakan yang langsung terlibat dalam pemerolehan, pengonsumsian, dan penghabisan produk/ jasa, termasuk proses yang mendahului dan menyusul tindakan ini". "Perilaku konsumen adalah studi unit-unit dan proses pembuatan keputusan yang terlibat dalam penerimaan, penggunaan dan pembelian, dan penentuan barang, jasa, dan ide" (Mowen \& Minor, dalam Etta dan Sopiah, 2013:7). 
METODOLOGI PENELITIAN

Paradigma Penelitian Kontruktivisme

Menurut Moleong (2004:49) "paradigma adalah kumpulan longgar dari sejumlah asumsi yang dipegang bersama, dikonsep atau proposisi yang mengarahkan cara berfikir dan penelitian atau sebagai cara mendasar untuk, menilai dan melakukan yang berkaitan dengan sesuatu secara khusus tentang visi realitas".

\section{Metode Penelitian Kualitatif}

Metode penelitian pada dasarnya merupakan cara ilmiah untuk mendapatkan data dengan tujuan dan kegunaan tertentu. Menurut Sugiyono (2017:8-9) "Metode penelitian kualitatif sering disebut metode penelitian naturalistik karena penelitiannya dilakukan pada kondisi yang alamiah (natural setting); disebut juga sebagai metode etnographi, karena pada awalnya metode ini lebih banyak digunakan untuk penelitian bidang antropologi budaya, disebut sebagai metode kualitatif, karena data yang terkumpul dan analisanya lebih bersifat kualitatif'.

\section{Tradisi Penelitian Studi Kasus}

Tradisi dalam penelitian ini adalah studi kasus. Menurut Danim (dalam Imam, 2013:112) "penelitian studi kasus dimaksudkan untuk mempelajari secara intensif, tentang latar belakang masalah keadaan dan posisi suatu peristiwa yang sedang berlangsung saat ini, serta interaksi lingkungan unit sosial tertentu yang bersifat apa adanya (given). Subjek penelitian dapat berupa individu, kelompok, institusi atau masyarakat. Penelitian studi kasus merupakan studi mendalam mengenai unit sosial tertentu dan hasil penelitian tersebut dalam memberikan gambaran luas, serta mendalam mengenai unit sosial tertentu".

\section{PEMBAHASAN}

\section{Strategi Komunikasi Bauran Pemasaran Dalam Meningkatkan Minat Beli Konsumen A. Produk (Product)}

PT. Ciputra Residence merupakan pengembang properti terbesar di Tangerang dengan mengusung membangun sebuah kawasan yang berskala kota mandiri dengan demikian PT. Ciputra Residence menghasilkan produk berupa hunian atau rumah dan berbagai proyek komersil lainnya, perumahan yang dibangun di kawasan Citra Raya dengan terus membangun fasilitas yang dapat dimanfaatkan konsumen atau para warganya sehingga dapat menambah nilai plus perusahaan terhadap konsumen. Dengan memfokuskan kenyamanan dan keamanan untuk konsumen, PT. Ciputra Residence memiliki produk hunian yang merupakan produk berkualitas mulai dari tampilan atau desain rumah yang modern dan stylish sehingga pemiliki rumah dapat merasa nyaman jika memiliki hunian tersebut. Dengan memanfaatkan lahan tanah yang luas PT. Ciputra Residence terus mengembangkan usaha serta inovasinya dalam membangun sebuah hunian yang menjadi dambaan konsumen. Dengan demikian teori yang digunakan peneliti dalam penelitian ini memiliki 
kesamaan dengan realita yang ditemukan pada PT. Ciputra Residence. Yaitu produk PT. Ciputra Residence berupa hunian atau rumah yang merupakan salah satu kebutuhan pokok bagi manusia. Produk hunian PT. Ciputra Residence termasuk dalam produk atau barang yang tahan lama, karena produk yang dihasilkan berupa bangunan yang berarti merupakan produk tidak bergerak sehingga produk tersebut dapat bertahan dengan lama karena bangunan yang didirikan terbuat dari bahan bangunan dengan material yang berkualitas dan tentunya dapat bertahan lama.

\section{B. Harga (price)}

Harga merupakan biaya yang dapat dibayar oleh konsumen dengan membayar sejumlah persyaratan yang dapat dibayar, biaya yang dapat dibayar tergantung dengan produk rumah yang dipilih oleh konsumen, selain rumah terdapat beberapa biaya yang lain yang dapat konsumen bayar, seperti luas tanah, luas bangunan, tipe bangunan rumah dan dokumen-dokumen atas kepemilikan rumah pun menjadi salah satu biaya yang harus dibayar oleh konsumen. Harga tersebut disesuaikan dengan tipe rumah yang dipilih konsumen, melalui teori yang sudah dipaparkan dapat dikaitkan dengan penelitian ini yaitu harga merupakan sejumlah uang yang harus konsumen bayar untuk mendapatkan produk yang diinginkan. Dengan demikian PT. Ciputra Residence akan membentuk strategi pemasaran terkait dengan kebutuhan konsumen tentu hal tersebut dilihat dari ekonomi konsumen, seperti gaji perbulannya, kemampuannya untuk membayar rumah setiap bulannya dan sebagainya. Dengan memperhatikan ekonomi konsumen perusahaan dapat memberikan solusi mengenai hunian atau rumah yang sesuai dengan ekonomi konsumen. Hal tersebut dapat membantu konsumen untuk memiliki sebuah hunian di kawasan dengan fasilitas yang lengkap.

\section{Promosi (Promotion)}

Dalam kegiatan strategi komunikasi pemasaran, promosi berguna untuk PT. Ciputra Residence dalam mempromosikan produk yang dihasilkan dengan tujuan konsumen dapat tertarik. Media sosial menjadi salah satu media yang digunakan PT. Ciputra Residence dalam melakukan kegiatan promosi kepada calon konsumen.

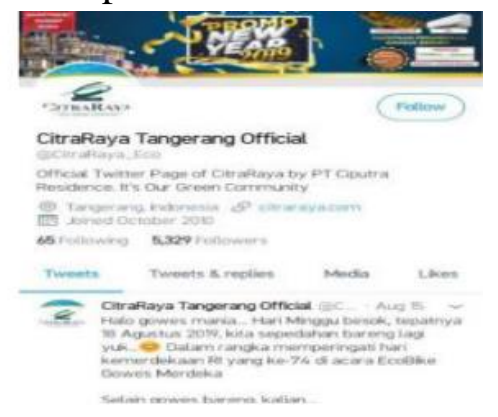

\section{Gambar 4.5 Media Sosial (Sumber : Twitter Citra Raya)}

PT. Ciputra Residence menggunakan berbagai media untuk melakukan promosi salah satu media yang digunakan adalah twitter, melalui media twitter PT. Ciputra Residence memberikan berbagai informasi terkait dengan kegiatan yang dilakukan, proyek terbaru perusahaan, maupun promosi diskon yang sedang berlangsung. Konsumen dapat dengan mudah mengakses media twitter yaitu mengetahui agenda yang akan berlangsung, menampilkan kegiatan berupa pembangunan proyek berupa rumah, hotel maupun apartemen. Melalui twitter 
ditampilkan juga hadiah yang dapat menarik minat beli konsumen. Hal tersebut merupakan salah satu bagian dari strategi pemasaran yang dilakukan PT. Ciputra Residence. menambah daya tarik atau beli konsumen.

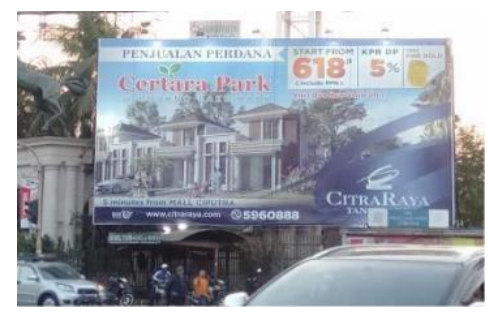

Gambar 4.6 Media Cetak Spanduk

Tidak hanya media sosial yang dijadikan sebagai sarana informasi untuk konsumen melainkan dilakukan pula media cetak berupa spanduk yang di pasang di jalan dengan harapan masyarakat yang melintas dapat melihat promosi berupa produk yang sedang dijadikan proyek PT. Ciputra Residence.

\section{Tempat (Place)}

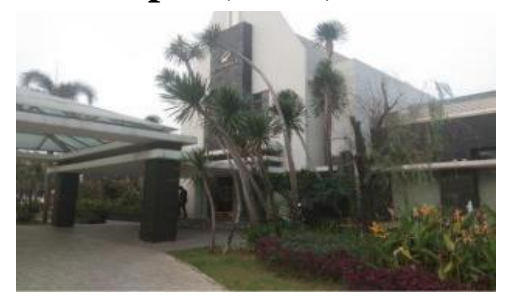

Gambar 4.8 Kantor Pemasaran Citra Raya

Dengan mengutamakan kenyamanan untuk konsumen kantor pemasaran Citra Raya didesign dengan bangunan yang modern dan ramah lingkungan karena sekitar halaman depan kantor dipenuhi tanaman hias agar kantor terlihat hijau.

Sesuai dengan fungsinya kantor pemasaran Citra Raya didalamnya memiliki berbagai macam contoh produk hunian atau rumah yang ada di Citra Raya dengan menggunakan miniatur rumah sebagai contoh yang dapat ditampilkan oleh sales kepada
konsumen.Selain itu konsumen akan mendapatkan pelayanan yang sangat ramah yang dilakukan oleh sales, konsumen dijamu dengan hangat. Melalui kantor pemasaran terjadinya proses pembelian seperti, pemilihan produk rumah, harga yang ditawarkan, proses pembayaran yang dapat dibayarkan konsumen, pengetahuan luas bangun dan luas tanah, fasilitas, dan lain sebagainya.

\section{E. Sumber Daya Manusia (People)}

Sumber daya manusia sangatlah penting dalam sebuah perusahaan temasuk di dalam perusahaan PT. Ciputra Residence yaitu sebagai penggerak dan

juga pemikir suatu perencanaan perusahaan agar perusahaan dapat berkembang dan maju menjadi lebih baik kedepannya, sumber daya manusia sangat dibutuhkan karena dapat menjadi sebuah aset sebuah perusahaan terutama yang bergerak dibidang property seperti PT. Ciputra Residence ini karena sumber daya manusia yang dimiliki haruslah memiliki pengalaman dalam bidang property sehingga kegiatan pemasaran yang dilakukan dapat berjalan efisien sehingga dapat menimbulkan timbal balik yang positif bagi kedua belah pihak yaitu sumber daya manusia dan perusahaan itu sendiri, di PT Ciputra Residence sumber daya manusia yang ada terus diberi dorongan serta motivasi agar dalam melakukan setiap pekerjaan dengan semangat yang tinggi. Selain itu sumber daya manusia harus dibekali dengan pengetahuan mengenai apa pekerjaan yang 
akan dilakukan agar fokus terhadap pekerjaan yang dilaksanakan.

\section{F. Proses (Process)}

Proses awal sebuah pembangunan perumahan yaitu mulai dari perencanaan lokasi, perancangan desain rumah, perencanaan bahan material yang digunakan kemudian penggunaan miniatur rumah sebagai salah satu contoh gambaran rumah yang akan dibangun sehingga sales dapat memberikan informasi mengenai rumah melalui sebuah miniatur. Selain itu melalui proses kepuasan konsumen juga dapat ditingkatkan seperti proses order, produksi hingga packaging. Sampai diterima oleh konsumen apakah produk yang dibangun adalah bangunan yang bagus dan berkualitas. Dengan demikian proses yang dilaksanakan sesuai dengan strandar operasional perusahaan sehingga akan menghasilkan mutu produk yang berkualitas. Dan peran people sangat diperlukan Karena merekalah yang akan menawarkan produk kepada konsumen secara langsung.

\section{G. Physical Evidence (Bukti Fisik)}

Lingkungan fisik di PT. Ciputra

Residence yaitu dengan menghadirkan sebuah perumahan dengan dekorasi yang tidak biasa mulai dari icon patung kuda yang berada di gerbang utama perumahan dan pilar-pilar yang menambah kesan mewah sebuah perumahan. Sebagai pengembang properti tentu perlu memikirkan masalah-masalah yang nantinya dapat terjadi di dalam perumahan oleh sebab itu perumahan di Citra Raya termasuk aman dalam geografis terutama mengenai banjir, selain itu tata letak dan perlengkapan bangunan sampai sistem pencahayaan pun bisa mempengaruhi keinginan konsumen untuk membeli hunian di Citra Raya.

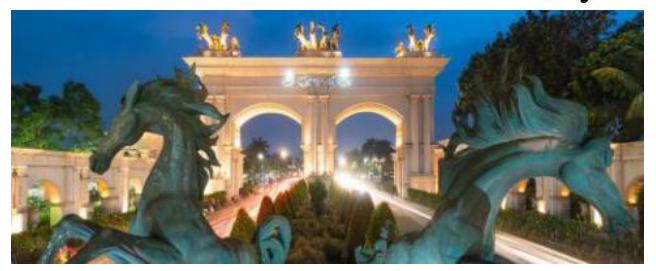

Gambar 4.9 Interior Gerbang Utama Citra Raya

(Sumber : https:/citraraya.com)

Dapat dilihat mulai dari interior yang menarik dapat menambah nilai plus untuk perusahaan dalam memberikan kepercayaan kepada konsumen mengenai tata letak dan lingkungan yang diciptakan dengan nyaman, asri dan hijau.

\section{KESIMPULAN}

$\begin{array}{ccc}\begin{array}{c}\text { Berdasarkan } \\ \text { pudah heneliti }\end{array} & \text { dapatkan denelitian yang } \\ \text { menggunakan } & \text { teknik wawancara, } \\ \text { observasi, } & \text { dan dokumentasi. } \\ \text { Peneliti } & \text { memberikan }\end{array}$

kesimpulan mengenai strategi komunikasi pemasaran PT. Ciputra Residence dalam menarik minat beli konsumen, sebagai berikut:

1). Strategi komunikasi pemasaran yang dilakukan bagian marketing dengan tujuan untuk meningkatkan minat beli konsumen dilihat sangat efektif dengan menggunakan unsur komunikasi pemasaran yaitu produk, promosi, harga dan tempat. Melalui produk yang ditampilkan dengan keunggulan yang ditawarkan Ciputra Residence kepada calon pembeli, kemudian promosi dengan 
memanfaatkan media yang dapat menarik dan membujuk konsumen seperti penggunaan media sosial, media cetak dan media konvensional. Semua media digunakan untuk mempromosikan produk maupun kegiatan di Ciputra Residence namun dari media tersebut perusahaan akan melihat media manakah yang memiliki peluang untuk membujuk konsumen, dengan demikian media tersebut akan difokuskan dengan harapan konsumen dapat tertarik. harga yang ditawarkan disesuaikan dengan pilihan atau tipe rumah yang diinginkan konsumen, dengan demikian konsumen akan mengetahui harga yang yang dapat dibayar, selain itu konsumen dapat memanfaatkan potongan harga.

2). Kendala-kendala yang didapat dalam menarik minat beli konsumen adalah pesaing antara PT. Ciputra Residence dengan pengembang properti lainnya yang juga bersaing untuk menarik minat beli konsumen unuk membeli produk hunian atau rumah.

\section{SARAN}

Berdasarkan kesimpulan yang peneliti uraikan maka peneliti ingin memberikan saran-saran sebagai berikut:

1). Saran untuk PT. Ciputra Residence yaitu meningkatkan infrastruktur karena selain produk yang diunggulkan konsumen akan melirik apakah infrastruktur yang ada dikawasan bisa dikategorikan dengan sesuai dengan harapan atau tidak.

2). Melakukan strategi yang dilakukan untuk menghadapi persaingan antara PT. Ciputra Residence dengan pengembang developer lainnya. PT. Ciputra Residence sudah memiliki banyak pengalaman mengenai properti oleh karena itu tinggal memanfaatkan hal tersebut sebagai suatu nilai unggul yang dapat dilakukan untuk menarik minat beli konsumen.

\section{DAFTAR PUSTAKA}

Alma, Buchari. 2005. Manajemen Pemasaran dan Pemasaran Jasa. Bandung: ALFABETA.

Gunawan, Imam. 2013. Metode Penelitian Kualitatif: Teori dan Praktik. Jakarta: PT. Bumi Aksara.

Herdiansyah, Haris. 2012. Metode Penelitian Kualitatif untuk IlmuIlmu Sosial. Jakarta: Salemba Humantika.

Hermawan. Agus. 2012. Komunikasi

Pemasaran. Jakarta: Erlangga

Kotler dan Keller. 2008. Manajemen Pemasaran Jilid 2. Jakarta: Erlangga.

Kotler, Philip. 2009. Manajemen Pemasaran. Jakarta: Erlangga.

Moleong, Lexy J. 1996. Metodologi

Penelitian Kualitatif. Bandung: PT. Remaja

Rodaskarya.

Moelong, Lexy j. 2009. Metode Penelitian Kualitatif. Bandung: PT.Remaja Rodaskarya.

Moleong, Lexy J. 2014. Metodologi Penelitian Kualitatif. Bandung: PT. Remaja 
Rodaskarya.

Mukhtar. 2013. Metode Praktis Penelitian

Deskriptif Kualitatif. Jakarta: GP. Press Group.

Mulyana, Deddy. 2016. Ilmu Komunikasi

Suatu Pengantar. Bandung: PT.

Remaja Rodaskarya.

Satori, Djam'an dan Komariah, Aan. 2017. Metodologi Penelitian Kualitatif.

Bandung: CV. Alfabeta.

Subagyo, Joko. 2015. Metode Penelitian Dalam Teori dan Praktik. Jakarta: Rineka Cipta.

Sunyoto, Danang. 2012. Dasar- Dasar

Manajemen Pemasaran. Yogyakarta: CAPS.

Suryanto. 2015. Pengantar Ilmu

Komunikasi. Bandung: Pustaka

Setia

Sugiyono. 2018. Metode penelitian

Kuantitatif, Kualitatif dan $R \& D$. Bandung:

\section{ALFABETA.}

Suwartono. 2014. Dasar- dasar Metodologi Penelitian. Yogyakarta: CV. Andi Offset.

Uchjana, Onong Effendy. 2005. Ilmu Komunikasi Teori dan Praktek. Bandung:

PT. Remaja Rodaskarya.
Uchjana, Onong Effendy. 2009. Ilmu Komunikasi Teori dan Praktek. Bandung:

PT. Remaja Rodaskarya.

\section{SKRIPSI}

Tuanggana, Tegar (2014). "Strategi

Komunikasi Pemasaran PT.

Ratna Motor Di Wilayah Jawa

Tengah dan DIY Dalam

Mempertahankan Posisi Toyota

Avanza Sebagai Market Leader

di Kelas LMPV”. Universitas

Diponegoro Semarang.

Tahir, Muh. Said HM (2014). "Strategi Komunikasi Pemasaran Radio Smart FM Makasar Dalam

Meningkatkan Jumlah

Pengiklan”. Universitas Islam Negeri

Alauddin Makasar.

Resmiati, Endah (2014). "Strategi

Komunikasi Pemasaran "Reebs

Cloth" Dalam Mempertahankan

Minat Belanja Pelanggan”.

Universitas Pembangunan

Nasional "Veteran".

SUMBER LAIN 
https://citraraya.com/

(akses pada tanggal 12 Agustus 2019, jam 21.01).

https://www.ciputradevelopment.com/id/

(akses pada tanggal 12 Agustus 2019, jam 21.04).

https://twitter.com/citraraya_eco

(akses pada tanggal 12 Agustus 2019, jam 21.05).

https://www.facebook.com/pages/category/P roduct-Service/Ciputra-Citra-RayaTAngerang-114465452661574/ (akses pada tanggal 12 Agustus 2019, jam

21.06).

https://www.instagram.com/citraraya/ (akses pada tanggal 12 Agustus 2019, jam 21.07).

https://www.google.co.id/maps/search/di+Jl. + Ecopolis+Avenue+Blok+VE.07+no.+0709+Cikupa,+Tangerang./@_

$\underline{6.2414913,106.5189336,16 z / \text { data }=! 3 \mathrm{ml} ! 4 \mathrm{~b} 1}$

(Akses pada tanggal 15 Agustus 2019, jam 10:19)

\section{JURNAL}

Utami Ruri Putri danSaputra Hendra (2017), "pengaruh produk terhadap minat beli sayuran organik di pasar sambas Medan”.

Hidayati Tri Asih,dkk (2013), "Pengaruh Citra Merek Terhadap Minat Beli dan Keputusan Pembelian Konsumen”.

Veronika (2016), "Pengaruh Iklan dan Brand Image Terhadap Minat Beli, Dengan Brand Image sebagai Variabel Mediasi”. 